\title{
IDENTITAS BUDAYA MUSIK GAMBUS DI PALEMBANG
}

\author{
Alfathul Mukarram \\ Program Pascasarjana, Universitas Negeri Semarang \\ E-mail: alfathulmukarram@gmail.com
}

\begin{abstract}
Abstrak
Musik gambus Melayu merupakan salah satu genre seni musik yang lahir dari perpaduan budaya Timur Tengah dan Melayu. Di Kota Palembang, aliran musik ini bukan genre baru, tetapi telah hadir sejak ratusan tahun lalu seiring bertumbuh kembangnya etnis Arab di bumi Sriwijaya. Masyarakat etnis Arab juga memiliki perilaku, kebiasaan, maupun keakraban terhadap masyarakat Kota Palembang. Beberapa etnis Arab yang ada di Kota Palembang dapat dikatakan sebagai minoritas. Akan tetapi, ada beberapa etnis (suku) Arab yang memunculkan identitas estetik masyarakat di Kota Palembang dengan mempertunjukan kesenian-kesenian mereka, salah satunya etnis Arab yang mempertahankan kebudayaan mereka melalui kesenian musik gambus. Musik gambus di Kota Palembang juga merupakan salah satu genre musik yang khas dan unik. Genre musik di Kota Palembang adalah perpaduan musik gambus klasik, musik gambus Melayu, dan musik gambus modern. Aliran seni musik ini kerap dilantunkan dalam berbagai hajatan warga Kota Palembang, mulai dari kelahiran, khitanan, hingga pernikahan.
\end{abstract}

Kata kunci: musik gambus, identitas budaya

\section{GAMBUS MUSIC IN PALEMBANG CITY: AN ANALYSIS OF CULTURAL IDENTITY}

\begin{abstract}
The music of Gambus Melayu was One genre of musical arts which is born from a blend of Middle Eastern culture and Melayu. In Palembang city, The music of Gambus Melayu is not a new genre. It has been there since hundreds of years ago, together with the development of Arab ethnicity on earth of Sriwijaya. Some Arab minor tribe gives esthetic value in arts performance in Palembang. They maintain it through Gambus Melayu music. Gambus music in Palembang is the combination between classic gambus, Melayu gambus, and modern gambus. It plays in traditional ceremonies and celebration such as the birth celebration, circumcision, and wedding parties.
\end{abstract}

Keywords: the music of gambus, cultural identity

\section{PENDAHULUAN}

Palembang adalah Ibu Kota Provinsi Sumatera Selatan, dan kota terbesar kedua di Sumatera setelah Medan. Palembang pernah menjadi Ibu Kota kerajaan bahari Budha terbesar di Asia Tenggara. Pada saat itu, Kerajaan Sriwijaya yang mendominasi Nusantara dan Semenanjung Malaya pada abad ke-9 juga membuat kota ini dikenal dengan julukan "Bumi
Sriwijaya". Kota Palembang merupakan salah satu kota di Provinsi Sumatera Selatan, sekaligus Ibu Kota yang memiliki slogan (Kota BARI), "BARI" (Bersih, Aman, Rapi, dan Indah). "Indah" menurut Immanuel Kant merupakan persepsi yang timbul melalui representasi dari suatu objek tertentu (Sugiharto, 2013:27). Palembang merupakan Ibu Kota multikultural, keberagaman budaya memberikan ciri dan jati 
diri atau identitas dari setiap budaya yang ada di Kota Palembang. Namun, budaya-budaya Palembang sering terlupakan dan jarang yang melestarikannya. Hal ini disebabkan karena kurangnya rasa peduli dan sikap kritis masyarakat dalam menghadapi adaya perkembangan moderenisasi zaman, sehingga masyarakat banyak yang terlena di zaman global yang serba instan sekarang ini.

Palembang merupakan pulau yang memiliki sejumlah etnis terasing dan mempunyai ciri khas tradisional. Etnis yang cukup tersorot oleh masyarakat Palembang dan beberapa kalangan berpendapat bahwa etnis Palembang merupakan kebudayaan hasil dari peleburan Bangsa Arab, Tionghoa, suku Jawa, dan Etnis lainnya. Dalam pandangan Liliweri (2014:1) identitas nasional kebudayaan adalah setiap usaha untuk memanusiakan manusia sesungguhnya, disusul dengan penjelasan tentang perkembangan definisi kebudayaan, wujud dan unsur-unsur kebudayaan, tujuan kebudayaan, peranan dan fungsi kebudayaan, sifat kebudayaan dan terakhir memahami makna peradaban.

Di Palembang, etnis Arab adalah sejumlah kelompok minoritas terutama yang ada di lingkungan Kota Palembang. Di Palembang tersendiri etnis minoritas di lingkungannya dikenal dengan nama "Wong Ayib" atau orang yang keturunan bangsa Arab yang benar-benar memiliki tradisi maupun keseniannya sendiri. Fenomena kesenian Arab yang mengandung nilai estetis dan nilai religius di Kota Palembang yaitu dari seni rupa (kaligrafi, ukiran kaligrafi, arsitektur masjid, songket, tanjak, dan furnitur dekoratif), seni tari (tari sufi), seni musik (sya'rofal anam, Marawis, barzanji, dan gambus).

Dalam hal ini yang dikaji adalah kesenian musik gambus sebagai fenomena kesenian di Kota Palembang. Musik gambus di Kota Palembang seringkali disebut musik gambus Melayu di mana perpaduan musik Arab dan ornamen Melayu. Pada tahun 1960 sampai 1970, Kota Palembang memiliki ratusan musisi yang membentuk ratusan kelompok seni musik gambus. Gambus ( $u$ 'd atau oud) merupakan salah satu instrumen yang terkenal dari seluruh insterumen musik peradaban Islam. Pendahuluannya adalah barbat (Persia), meskipun jenis gambus yang lebih awal ada yang menggunakan belly dari sejenis kulit. Bila belly terbuat dari kayu berarti diadopsi dari $o$ 'd atau oud (wood=kayu). Gambus awalnya lebih luas digunakan dalam musik religius Islam. Instrumen pendukung tambahan dalam ansambel musik gambus kadang-kadang dengan seperangkat rebana atau marwas, gendang kecil dengan kedua sisinya tertutup membran (jenis kulit) yang dipukul dengan tangan (hand drum). Nuansa gambus berkaitan dengan ekstensif dengan ornamen-ornamen budaya Timur Tengah seperti tipe musik qobuz atau kobza. Satu hipotesis menjelaskan bahwa kedatangan gambus diberikan untuk orang-orang Arab dengan perkembangan Islamisasi Malaka pada abad ke-15 (Anis, 1993:20).

Hipotesis ini memberikan penjelasan bahwa orang Persia dan orang Arab telah melakukan perdagangan di kepulauan Melayu pada awal abad ke-9 dan instrumen ini dibawa ke kapalkapal mereka untuk hiburan pribadi di dalam perjalanan dari barbad qanbus dan $u d$ yang mirip dengan gambus. Gambus diperkenalkan oleh para pedagang ketika perdagangan sepanjang Malay Archipelago. Kini berjalannya waktu kelompok seni musik gambus Melayu di Kota Palembang tidak lebih dari sepuluh grup, tersisah empat grup musik gambus yang eksistensinya dan identitas kebudayaannya yang terus berkembang di Kota Palembang seperti grup Al-Mubarok, Mozaig, dan lainnya.

Banyaknya masyarakat Kota Palembang yang mengapresiasi maupun memandang kesenian musik gambus sebagai kesenian yang estetis, dikarenakan tidak terlepasnya kekerabatan atar orang pribumi dan etnis Arab di Kota Palembang. Aliran musik gambus yang berdasarkan pertunjukan-pertunjukan musik gambus di beberapa jajaran Kota Palembang merupakan seni yang berpengaruh kuat bagi anak muda sehingga mereka mengepentingkan keakraban etnis Arab. Banyaknya musik gambus di Kota Palembang bernuasa aliran baru yang bisa diterima masyarakat Palembang seperti gambus Sriwijaya, dan gambus padang pasir. 


\section{MUSIK GAMBUS DI PALEMBANG Sejarah Masuknya Kesenian Islam di Kota Palembang}

Penyebaran Agama Islam di Indonesia tidaklah bersamaan waktunya antara daerah yang satu dengan yang lainnya. Islam pada awal kedatangannya di Indonesia disebarkan dengan jalan kedamaian.Pada waktu sejak dibuka Terusan Suez terjadi arus migrasi orang Arab dan Mesir masuk Hindia Belanda tahun 1870 hingga setelah 1888 , mereka membawa alat musik dan bermain musik Gambus. Dengan perkembangan teknologi elektronik sekitar tahun 1950 maka mulai diperkenalkan pengeras suara, gitar elektrik, bahkan perkembangan kyboard. Dan tak kala penting adalah perkembangan industri rekaman sejak tahun 1950. Hal ini tercemin dari penyebaran Islam di tanah-tanah Melayu, yang dijalankan dengan penuh kedamaian dan persahabatan maupun kekerabatan. "Masuknya Islam di negeri-negeri Melayu ini nampaknya mempunyai keistimewaan sendiri, yaitu dengan jalan damai dan berangsur, jarang sekali dengan kekerasan dan diterima dengan suka-rela oleh penduduk meskipun tidak sekaligus" (Hamka dalam Sunarto, 1994:81). Terdapat beberapa kesimpangsiuran waktu, kapan Islam masuk ke Indonesia. Beberapa sejarawan berbeda pendapat akan hal ini. Namun, titik temu terjadi pada kemunculan kerajaan Islam pertama di Nusantara, yaitu kerajaan Samudera Pasai di Aceh Utara, pada abad ke-13. Demikianlah, bahwa karena jalur-jalur perdaganggan antara Melayu dan Islam, maka sampailah pedagangpedagang Islam ke pantai utara Sumatera. Dan tentang berdirinya Kerajaan Islam pertama, Samudera Pasai, pada abad ke-13, belum menjamin pada abad tersebut Islam yang baru datang langsung mendirikan kerajaan.

Adapun yang disebut oleh Ricklefs (dalam Sunarto, 1994:82), para pembawa Islam di Indonesia berasal dari berbagai daerah atau negeri, seperti: Gujarat, Arab, Mesir, dan Persia. Dapat dikatakan bahwa daerah-daerah tersebut sebagai sumber Islam di Indonesia. Beberapa teori mengatakan, bahwa Islamisasi di Indonesia lebih cenderung kepada relasi perdagangan dan lewat kaum mistik Islam. Oleh karena itu, ajaran mistik jelas merupakan bagian dari Islamisasi, walupun perannya yang pasti belum jelas. Namun, faktor dominan dalam Islamisasi di Indonesia adalah perdagangan.

Kemungkinan bahwa perdagangan merupakan pendorong terhadap Islamisasi, karena pada penguasa Indonesia yang terlibat dalam perdaganggan barangkali beranggapan bahwa penganut agama seperti yang dianut sebagian pedagang itu adalah sangat bermanfaat. Islamisasi di Indonesia, terutama di Pulau Sumatera, tidak memakan waktu yang begitu lama. Hal ini karena pengaruh Hinduisme dan Budhisme di pulau tersebut kurang begitu ketat. Hanya ada satu wilayah bekas Kerajaan Sriwijaya, Palembang dan Sekitarnya, yang mempunyai sedikit pengaruh Hinduisme dan Budhisme. Dengan begitu Islam dapat dengan mudah tersebar luas di pulau Sumatera tanpa menemui hambatan yang berarti.

Pengaruh yang diberikan Islam kepada masyarakat, memberikan keterangan dan memiliki sifat asasi insan itu ialah akal, dan unsur hakikat inilah yang menjadi perhubungan antara dia dan hakikat semesta. Demikian juga kedatangan Islam dikepulauan Melayu di Indonesia yang membawa rasionalisme dan pengetahuan akhlak serta menegaskan suatu system masyarakat yang terdiri dari individuindividu. Jadi Islam membawa peradaban yang mudah diterima, intelektualitasme, dan ketinggian budi insan di Tanah Melayu. Unsur-unsur kesenian Islam yang terdapat di kebudayaan Melayu salah satunya adalah alat musik Gambus di Kota Palembang, di Arab dikenal dengan nama ' $u d$. Gambus tersebut sudah beradaptasi dengan wilayah setempat. Di Indonesia sendiri terdapat ukuran dan bentuk yang berbeda-beda. Walaupun bentuk ukurannya berbeda, tetapi suara yang dihasilkannya tetap bernuansa Timur Tengah.

\section{Bentuk dan Struktur Kesenian Gambus di Kota Palembang}

Musik Gambus di Kota Palembang merupakan kelompok musik yang beraliran gambus klasik, gambus melayu, dan gambus modern sebagai tema aransemennya. Dengan 
membawakan aransemen yang lebih modern, kelompok-kelompok musik gambus lebih mudah diterima oleh masyarakat di berbagai kalangan. Lagu-lagu yang sering dibawakan oleh beberapa musik di Kota Palembang mulai dari lagu-lagu gambus klasik, gambus melayu, salawat, khasidah, gambus modern, lagu dangdut yang diubah syairnya, dan lagu-lagu pop arabik.

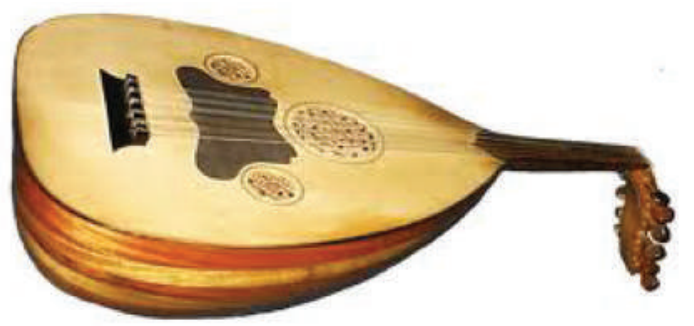

Gambar 1. Instrumen Musik Gambus (Sumber: http://4.bp.blogspot.com/-x0obav0Wicc/ UZJcTw0SzRI/AAAAAAAAAAM/g76tgMv3tNM/s1600/ index.jpg)

Dengan melihat sejarah awal musik gambus di Kota Palembang berakar dari Qasidah, yang berasal dari kedatangan dan penyebaran Agama Islam di Nusantara pada tahun 6351600 dari Arab, Gujarad dan Persia, sifatnyas membaca syair "Salawat Badar" dan kemudian dinyanyikan. Oleh sebab itu awalnya syair Salawat Badar adalah rangkaian salawat berisikan tawassul dengan nama Allah SWT, dengan junjungan Nabi SAW, meruju menjadi suatu nyanyian maupun pertunjukan, dan secara berangsur kemudian dipakai juga untuk mengiring tarian. Musik gambus di Kota Palembang adalah suatu musik yang khas, unik, genre musik yang dimana perpaduan musik gambus klasik, musik gambus Melayu, dan musik gambus modern.

Diantara kelompok-kelompok musik gambus di Kota Palembang, ada empat kelompok yang eksistensinya terus berkembang di lingkungan masyarakat dan lebih lengkap dalam perbendaharaan lagu, alat musik, dan ditunjang dengan personil yang masih muda dan daya kreativitasnya pun lebih tinggi. Dari keempat kelompok-kelompok musik gambus yang eksis, sudah terkenal di wilayah Kota Palembang dan sekitarnya. Kepopuleran kelompok musik ini ditandai dengan seringnya menjadi bintang tamu di pentas-pentas musik, mulai dari acara hajatan, syukuran, pengajian, dan acara-acara penting lainnya. Kebanyakan dari ke empat kelompokkelompok musik gambus yang eksis, tampil di acara-acara hajatan pernikahan masyarakat Kota Palembang hingga luar Kota Palembang, dan selalu mendapat tanggapan yang positif dari penonton maupun masyarakat yang berapresiasi dalam pementasan kelompok-kelompok musik ini.

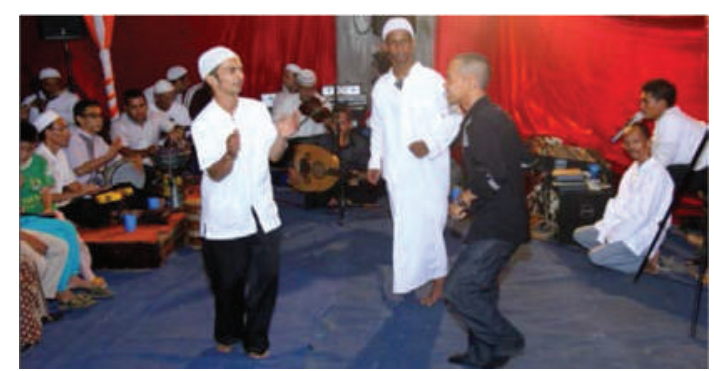

Gambar 2. Salah Satu Kelompok Musik

Gambus di Kota Palembang (Foto: Alfathul Mukarram, 2015)

Sebelum pementasan, latihan merupakan hal yang wajib dilakukan oleh para kelompokkelompok musik gambus di Kota Palembang, karena mereka harus benar-benar menguasai materi dari musik yang akan dibawakannya. Di samping itu, menurut Pak Syarif yang merupakan salah satu tokoh dari kelompokkelompok musik gambus yang ada di Kota Palembang, dan Pak Syarif adalah manajer utama dari kelompok musik gambus AlMubarok dan juga salah satu pengamat musik gambus, bahwa fisik dan mental dari beberapa kelompok musik gambus yang ada di Kota Palembang juga harus mereka persiapkan agar saat di panggung atau saat pentas mereka dapat berekspresi secara sempurna. Meskipun demikian, terdapat hambatan-hambatan dalam mereka berekspresi saat mereka mementaskan musik mereka, baik dari dalam ataupun dari luar diri mereka sendiri.

Seperti yang dikemukakan oleh Jamalus (1988:1), bahwa musik adalah suatu hasil karya seni bunyi dalam bentuk lagu atau komposisi- 
komposisi musik yang mengungkapkan pikiran dan perasaan penciptanya melalui unsur-unsur musik yaitu irama, melodi, harmoni, bentuk atau struktur dan ekspresi sebagai satu kesatuan.

\section{Irama}

Irama musik yang dimainkan oleh beberapa kelompok-kelompok musik gambus dipalembang bermacam-macam tergantung lagu yang mereka mainkan, musik gambus di Kota Palembang cenderung untuk membuat "beat" yang sederhana namun indah bila didengarkan untuk menuangkan karyanya, namun tak jarang pula menggunakan irama yang rumit pada beberapa lagu untuk menunjukkan kualitas bermusik. Perkusi dalam kelompok- kelompok musik gambus di Kota Palembang memiliki peranan yang sangat penting, dalam hal ini gendang dumbuk (darbuoka). Selain sebagai pengatur ritme dan tempo, darbuoka juga sebagai penentu irama apa yang akan dimainkan. Jika pemain darbuoka menghendaki irama tertentu maka instrumen yang lain seperti gendang chalti, gendang double, drum, bas, dan lain-lain juga harus mengikuti sehingga harmonisasi lagu tetap terjaga.

Ada 5 jenis irama pukulan wajib perkusi darbuoka yang digunakan oleh beberapa kelompok musik gambus di Kota Palembang dalam setiap pementasan, yakni sebagai berikut.

1. Irama Sarah

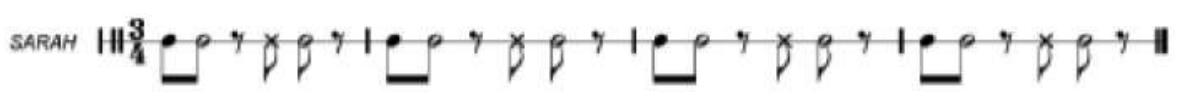

Notasi 1. Irama Sarah pukulan perkusi darbuoka.

2. Irama Defeh

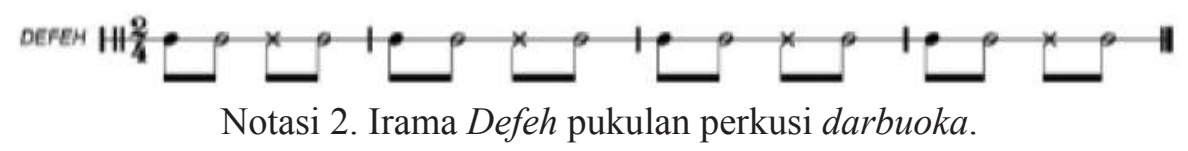

3. Irama Zafin (Marawis)

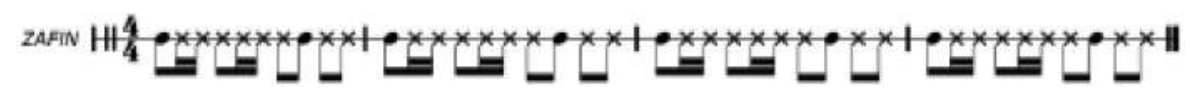

Notasi 3. Irama Zafin pukulan perkusi darbuoka.

4. Irama Misri (Rumba)

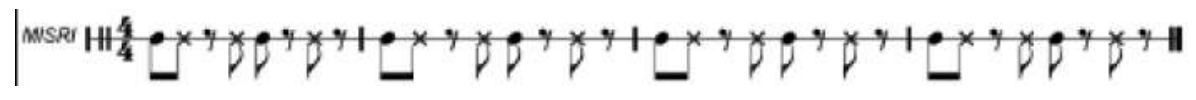

Notasi 4. Irama Misri pukulan perkusi darbuoka.

5. Irama Baladi (pengembangan irama Defeh)

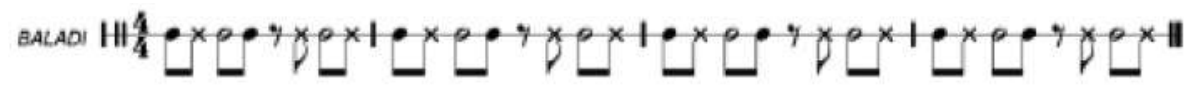

Notasi 5. Irama Baladi pukulan perkusi darbuoka.

Keterangan: ${ }^{P}=$ dung $P_{=\text {teng }} \Gamma_{=\text {tak }}$ 
Setelah diamati dari ke lima jenis irama darbuoka yang wajib digunakan oleh beberapa kelompok-kelompok musik gambus di Kota Palembang, sangat jelas sekali perbedaan dari masing-masing irama. Apabila lagu berbirama $3 / 4$ maka menggunakan irama Sarah, irama Sarah banyak ditemui di koleksi lagu-lagu Mashabi. Apabila lagu berbirama 2/4 maka menggunakan irama Defeh. Lagu-lagu yang berirama Defeh biasanya lagu-lagu nasyidaria. Kemudian jika lagu berbirama 4/4 maka menggunakan Zafin atau Misri. Irama Zafin lebih lambat daripada Misri. Contoh lagu yang menggunakan irama Zafin atau biasanya lebih populer dengan sebutan Marawis adalah lagu Laila Canggung. Irama Misri atau Rumba ada pada koleksi lagu-lagu Umi Kulsum. Irama Baladi merupakan pengembangan irama Defeh. Jika irama Defeh bertempo cepat, irama Baladi bertempo lambat tapi ada lebih banyak variasi ketukan di dalamnya sehingga irama ini tetap kelihatan tidak sepi.

\section{Melodi}

Melodi adalah susunan rangkaian nada (bunyi dengan getaran teratur) yang terdengar berurutan serta bersama dengan mengungkapkan suatu gagasan. Menurut Pak Syarif selaku pendiri ketua kelompok dari salah satu kelompok musik gambus di Kota Palembang, musik gambus di Kota Palembang menggunakan tangga nada minor harmonis dan arabic scale. Tangga nada minor harmonis adalah A, B, C, D, E, F, G\#, A. Arabic scale bersifat monofonik, artinya tidak berdasarkan susunan kontrapung atau harmoni seperti musik Barat. Tangga nada yang dipakai adalah yang disebut maqam (jamak: maqamat), yaitu susunan nada-nada yang tidak detil sempurna (well tempered) seperti halnya musik Barat. Sifat dari monofonik ini terlihat pada musik qasidah yang berupa nyanyian tunggal iringan rabana, jadi melodi hanya dengan iringan pukulan irama.

Susunan maqam mengenal $1 / 4$ nada yang tidak dipunyai tangga nada Barat (hanya $1 / 2$ nada). Contoh adzan memiliki liku-liku melodi yang rumit. Sehingga maqam tidak bisa ditulis dalam notasi Barat. Dengan demikian, Musik Arab tidak ada susunan harmoninya. Susunan melodi arab adalah unisono, yaitu melodi diimitasi dengan suara gambus secara unisono. Selain menggunakan tangga nada minor harmonis dan arabic scale, dalam beberapa lagu yang dimainkan oleh musik gambus di Kota Palembang juga menggunakan tangga nada minor melodis dan tangga nada mayor. Tangga nada ini biasanya digunakan dalam lagu-lagu dangdut dan pop.

Waktu seseorang menyanyikan sebuah lagu, ia menyanyikan syair lagu. Tinggi rendahnya syair lagu yang dinyanyikan sesuai dengan titinada-titinada dari notasi lagu tersebut. Panjang pendeknya suku kata, dan kata dari syair lagu bergantung pada nilai titinadatitinada dan tanda istirahat dalam notasi lagu. Singkatnya syair lagu yang dinyanyikan sesuai dengan melodi. Pada kelompok-kelompok musik gambus di Kota Palembang ada 5 jenis lagu yang biasa dibawakan pada setiap pentas, yaitu: salawat, qasidah, gambus klasik, gambus Melayu, gambus modern, dangdut, dan pop. Berikut ini adalah salah satu lagu wajib dari beberapa lagu yang sering dimainkan kelompokkelompok musik gambus yang ada di Kota Palembang. 
Melodi Lagu Salawat Badar (Salawat):

Song:

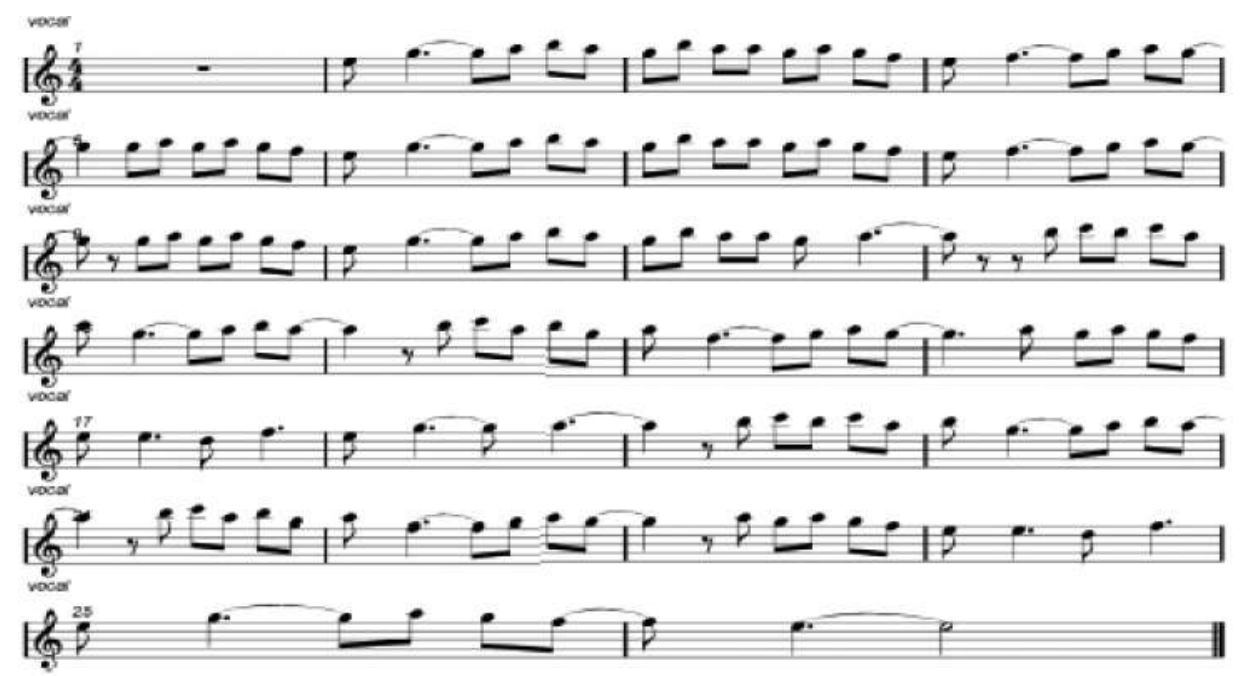

Notasi 6. Melodi lagu Salawat Badar

Reff:

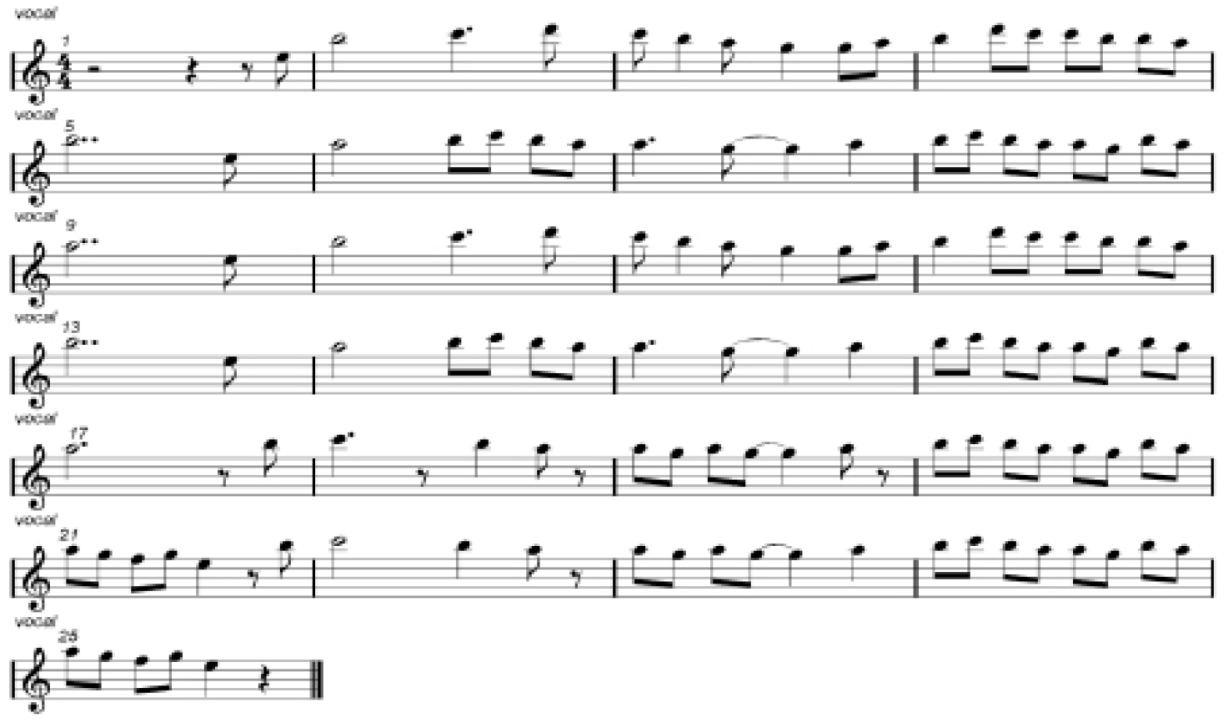

Notasi 7. Melodi reff lagu Salawat Badar

Dari contoh lagu di atas, yang sering dan wajib dibawakan oleh beberapa kelompok musik gambus di Kota Palembang, dapat dilihat bahwa melodi-melodi yang dimainkan bernuansa Islami, sehingga seseorang yang mendengarnya akan merasakan suasana Arab. Beberapa lirik lagu menggunakan bahasa Arab dan mengungkapkan tentang hal yang berhubungan dengan Islam, misalnya tentang rasa syukur kepada Allah SWT, penghormatan kepada Nabi Muhammad SAW. Setiap pementasan musik gambus Kota Palembang juga menggunakan teknik legato (membunyikan nada secara bersambung), staccato (memperpendek nadanada sehingga terdengar terputus-putus), vibrato (membunyikan nada dengan memberikan perubahan berkala pada intensitas nada, warna nada, dan tinggi nadanya). 


\section{Harmoni}

Pembawaan setiap lagu, beberapa kelompok musik gambus di Kota Palembang selalu memperhatikan bagian-bagian dari unsur musik yang disebut harmoni. Unsur harmoni dilakukan supaya terjadi kesesuaian antara irama dan melodi. Hal ini ditunjukkan pada lagu-lagu yang dimainkan oleh kelompok musik gambus di Kota Palembang. Unsur harmoni meliputi penggunaan berbagai macam akord beserta dengan progesi perpindahan susunannya, penggabungan nada yang harmonis akan membentuk sebuah lagu yang harmonis pula. Berikut beberapa contoh perpindahan akord yang dimainkan oleh beberapa kelompok musik gambus di Kota Palembang.

Perpindahan Akord Lagu Salawat Badar:

$$
\begin{aligned}
& \text { Song: } \quad|\mathrm{G} \ldots| \text { Am . . F . . } \quad \text { G . . G . . Am . . } \\
& |\mathrm{F} \ldots| \mathrm{G} \ldots|\mathrm{G} \ldots| \mathrm{Am} \ldots|\mathrm{Am} \ldots| \mathrm{G} \ldots \\
& |A m \ldots| F_{\ldots} \ldots\left|G_{\ldots} \ldots\right| \text { Em . . . G . . Am . . . } \\
& |\mathrm{G} \ldots| \mathrm{Am} \ldots|\mathrm{F} \ldots| \mathrm{G} \ldots|\mathrm{Em} \ldots| \mathrm{G} \ldots|\mathrm{Am} \ldots| \\
& \text { Reff: } \quad \mid \text { Em ...|Em ...|Em ...|Em ...|Am ...|Am . . . } \\
& |\mathrm{Am} \ldots| \mathrm{Am} \ldots \mid \mathrm{Em} \text {...|Em . . .|Em . . . Em . . . } \\
& \mid \text { Am . . . Am . . A Am . . A Am . . } .|\mathrm{C} \ldots| \mathrm{G} \ldots \\
& |\mathrm{G} \ldots| \mathrm{Am} \ldots|\mathrm{C} \ldots| \mathrm{G} \ldots .|\mathrm{G} \ldots| \mathrm{Am} \ldots \mid
\end{aligned}
$$

Notasi 13. Perpindahan akord reff lagu Salawat Badar

Harmonisasi pada beberapa kelompok musik gambus di Kota Palembang pada lagulagu gambus klasik pada umumnya adalah unisono, yaitu melodi diimitasi dengan suara gambus secara unisono. Biasanya melodi Arab dipresentasikan sebagai tangga nada minor dalam sistem tangga nada musik Barat, sehingga juga mengikuti kontrapung atau harmoni musik Barat. Dan ini yang dipakai dalam musik Arab modern.

Bentuk atau struktur lagu merupakan hubungan antara musik dan kalimat, sehingga membentuk makna dalam sebuah lagu. Maknamakna yang terkandung dalam lirik lagu gambus yang dibawakan oleh beberapa kelompok musik gambus yang eksistensinya cukup dilirik masyarakat Kota Palembang ini bersifat sederhana. Sederhana artinya bentuk lirik dan struktur lagu pada umumnya berupa percakapan, dan mengandung makna yang sesuai dengan kehidupan realita yang ada. Dengan adanya bentuk struktur lagu yang sederhana, makna yang terkandung dalam lirik akan lebih mudah diterima oleh para pendengar ataupun masyarakat Palembang. Tema dalam lagu pun akan jelas dan mudah dipahami oleh pendengar. Lirik lagu-lagu gambus yang dibawakan oleh beberapa kelompok yang ada di Palembang mengandung unsur islami di dalamnya. Bahkan sebagian besar lagu-lagunya berbahasa Arab dan mengungkapkan tentang hal yang berhubungan dengan islam, misalnya tentang rasa syukur kepada Allah SWT, penghormatan kepada nabi Muhammad SAW, bahkan tentang mudahmudih yang sedang kasmaran, dan lain-lain.

Berikut contoh lirik lagu "Salawat Badar" yang wajib dibawakan oleh beberapa kelompok musik gambus di Kota Palembang.

Shalaatullaah Salaamul laah 'Alaa Thaaha Rasuulillaah

(Rahmat dan keselamatan Allah, Semoga tetap untuk Nabi Thaaha utusan Allah)

Shalaatullaah Salaamulleah 'Alaa Yaa Siin Habiibillaah

(Rahmat dan keselamatan Allah, Semoga tetap untuk Nabi Yasin kekasih Allah')

Tawassalnaa Bibismi llaah Wabil Haadi Rasuulillaah 
(Kami berwasilah dengan berkah "Basmalah", Dan dengan Nabi yang menuniukkan lagi utusan Allah,)

Wakulli Mujaahidin Lillaah Bi Ahlil Badri Yaa Allaah

(Dan seluruh.orang yang beriuang .karena Allah, Sebab berkahnya sahabat ahli badar ya Allah.)

llaahi Sallimil Ummah Minal Aafaati Wanniqmah

(Ya Allah, semoga Engkau menyelamatkan ummat, Dari bencana dan siksa,)

llaahi Sallimil Ummah Minal Aafaati Wanniqmah

(Ya Allah, semoga Engkau menyelamatkan ummat, Dari bencana dan siksa,)

Wamin Hammin Wamin Ghummah Bi Ahlil Badri Yaa Allaah

(Dan dari susah dan kesempitan, Sebab berkahnya sahabat ahli bariar ya Allah')

Ilaahi Najjinaa Waksyif Jamii'a Adziyyatin Wahrif

(YaAIlah semoga Engkau selamatkan kami dari semua yang menyakitkan,

Dan semoga Engkau (Allah) meniauhkan tipu dan daya musuh-musuh,)

Ilaahi Najjinaa Waksyif Jamii'a Adziyyatin Wahrif

(Ya AIlah semoga Engkau selamatkan kami dari semua yang menyakitkan,

Dan semoga Engkau (Allah) meniauhkan tipu dan daya musuh-musuh,)

Makaa idal 'idaa wal thuf Bi Ahlil Badri Yaa Allaah

(Dan semoga Engkau mengasihi kami, sebab berkahnya sahabat Ahli Badar Ya Allah).

Dalam beberapa bentuk maupun struktur musik gambus yang ada di Kota Palembang tidak terlepas dari tempo. Dikarenakan tempo juga menjadi suatu faktor terpenting dari pertunjukan musik gambus yang ada di Kota Palembang. Tempo ialah tingkatan kecepatan dalam musik yang diukur dengan sebuah alat yang dinamakan metronom dan perubahanperubahan dalam kecepatan lagu tersebut. Tanda tempo dibagi dalam tiga bagian yaitu; tempo lambat, sedang, dan tempo cepat. Dari mulai tempo iringan musik dengan metronom menunjukkan angka 40 sampai dengan 69, tempo sedang (andante) dengan metronom menunjukan angka 70 sampai dengan 100, dan tempo cepat (allegretto) dengan metronom menunjukkan angka 101 sampai dengan 208, semua atas dasar konsep pembawaan dalam aksi panggung musik gambus yang ada di Kota Palembang. Salah satu faktor yang dianggap penting dalam menentukan reaksi suasana hati terhadap musik adalah tempo musik yang dibawakan. Untuk menunjukkan suasana gembira, maka dipakai tempo sedang hingga tempo cepat. Tempo lambat umumnya dipakai untuk yang berhubungan dengan hal-hal musibah, kekecewaan, kesedihan, dan kerinduan hati.

Bentuk dan struktur musik gambus yang ada di Kota Palembang tidak terlepas dari ekspresi. Ekspresi adalah cara seseorang membawakan lagu dalam hal penyesuaian dengan sifat lagunya. Misalnya yang berkaitan dengan cepat lambatnya lagu, kuat lembutnya lagu, serta makna kata-kata lagu. Dalam hal ini ekspresi meliputi ekspresi pemain musik dan vokalis. Selain kendang atau chalti dan pemain keyboard, personil yang lain seperti pemain gambus, pemain bas, dan vokalis dapat bergerak secara bebas. Artinya mereka tidak hanya diam di tempat, karena mereka dapat bergerak bebas ke setiap sudut panggung menyesuaikan beat atau irama lagu. Lain halnya dengan pemain kendang dan pemain keyboard, mereka tidak dapat bergerak dengan bebas di atas pentas.

Dalam kelompok musik gambus yang ada di Kota Palembang terdapat 2 cara penyajian musik gambus mereka. Yang pertama adalah tidak semua kelompok pemain musik gambus yang ada di Kota Palembang memakai penyajian yang pertama ini. Semua pemain musik duduk di atas kursi maupun berdiri, sedangkan vokalis tetap berdiri sewaktu membawakan lagu. Cara penyajian yang pertama ini biasanya dilakukan pada acara-acara pernikahan, event daerah dan event-event besar lainnya. Biasanya lagu-lagu yang dibawakan lebih bersifat menghibur. Cara penyajian yang kedua adalah pemain musik dan vokalis duduk bersila. Posisi seperti ini biasanya dilakukan pada acara pengajian atau acara-acara lain yang melibatkan penceramah. Lagu-lagu 
yang dibawakan mengikuti alur tausiah sehingga lebih bersifat komunikatif antara penceramah, pendengar dan kelompok musik. Dalam cara penyajian ini biasanya sudah ada kesepakatan antara penceramah dan pihak pemusik tentang tema tausiah, alur pembicaraan dan lagu-lagu yang akan dibawakan. Hal ini dilakukan supaya tidak terjadi missedcommunication dalam acara tersebut. Baik cara penyajian yang pertama maupun kedua semuanya tergantung permintaan dari penyelenggara acara.

\section{Musik Gambus sebagai Identitas Budaya}

Liliweri (2007:48) menyebutkan bahwa kebudayaan adalah kompleks dari keseluruhan pengetahuan, kepercayaan, kesenian, hukum, adat istiadat, dan setiap kemampuan lain dan kebiasaan yang dimiliki oleh manusia sebagai anggota suatu masyarakat. Diperkuat oleh Koentjaraningrat (2000:181) yang mengatakan bahwa kebudayaan berasal dari bahasa Sansekerta buddhayah, yaitu bentuk jamak dari buddhi yang berarti budi atau akal. Dengan demikian, kebudayaan dapat diartikan dengan hal-hal yang berkaitan dengan akal. Dalam bahasa Inggris, kebudayaan disebut culture, yang berasal dari kata Latin Colere, yaitu mengolah atau mengerjakan. Bisa diartikan juga sebagai mengolah tanah atau bertani. Dalam ilmu antropologi, kata budaya adalah daya dari budi yang berupa cipta, rasa, dan karsa, sedangkan kebudayaan merupakan hasil dari cipta, rasa, dan karsa. Kata budaya di sini hanya dipakai sebagai singkatan dari kebudayaan dengan arti yang sama.

Menurut Koentjaraningrat (2000:186) wujud kebudayaan ada tiga yaitu:

a. Wujud kebudayaan sebagai suatu kompleks dari ide-ide, gagasan, nilai, norma, dan peraturan.

b. Wujud kebudayaan sebagai suatu tindakan dari manusia dalam masyarakat.

c. Wujud kebudayaan sebagai benda-benda hasil karya manusia.

Walaupun setiap masyarakat mempunyai kebudayaan yang berbeda satu dengan yang lainnya, namun kebudayaan mempunyai sifat hakikat yang berlaku umum bagi semua kebudayaan. Sifat hakikat kebudayaan adalah ciri setiap kebudayaan (Soekanto 2012:160). Sifat hakikat kebudayaan tersebut adalah sebagai berikut.

a. Kebudayaan terwujud dan tersalurkan lewat perilaku manusia.

b. Kebudayaan telah ada terlebih dahulu mendahului lahirnya suatu generasi tertentu dan tidak akan mati dengan habisnya usia generasi yang bersangkutan.

c. Kebudayaan diperlukan oleh manusia dan diwujudkan tingkah lakunya.

d. Kebudayaan mencakup aturan-aturan yang berisikan kewajiban-kewajiban, tindakan-tindakan yang diterima dan ditolak, tindakan-tindakan yang dilarang dan tindakan-tindakan yang diizinkan.

Berbagai definisi dan pernyataan mengenai kebudayaan di atas, dapat diperoleh pengertian bahwa kebudayaan merupakan sesuatu yang akan mempengaruhi tingkat pengetahuan dan meliputi sistem ide atau gagasan yang terdapat dalam pikiran manusia, sehingga dalam kehidupan sehari-hari kebudayaan itu bersifat abstrak. Perwujudan kebudayaan adalah bendabenda yang diciptakan oleh manusia sebagai makhluk yang berbudaya berupa perilaku dan benda-benda yang bersifat nyata berupa sebuah karya seni yang semuanya ditujukan untuk manusia dalam melangsungkan kebutuhan dalam hidup bermasyarakat.

Cahyono dan Jazuli (1996) menyampaikan bahwa identitas erat hubungannya dengan makna yang berupa simbol, jati diri yang menunjuk kepada suatu pribadi. Identitas berfungsi sebagai filter atas pengaruh yang tidak sesuai dengan norma budaya masyarakat tertentu. Identitas akan bertahan hidup apabila diperkuat dengan cara mencari makna dalam masa lampau dan penjelasan masa kini.

Kinasih (2007:3) mengemukakan bahwa identitas menjadi sebuah keniscayaan yang melekat dalam hubungan antar manusia karena keberadaan seseorang senantiasa menjadi bagian dari sebuah kelompok etnik, agama, tradisi dan bahasa dalam sebuah sistem kebudayaan tertentu. Tidak ada sesuatu yang berdiri dengan sendirinya, sesuatu diluar dirinya akan 
memasukkan dirinya ke dalam kategori identitas tertentu.

Setiap individu memerlukan identitas untuk memberinya sense of belonging dan eksistensi sosial. Di dalam keseharian masyarakat kita, terdapat sejumlah identifikasi budaya sederhana. Misalnya, masyarakat mengidentifikasi orang Bali sebagai pemeluk Hindu, orang Aceh sebagai pemeluk Islam, atau orang Flores sebagai pemeluk Katolik. Identitas adalah sebuah proses yang tidak terberi (given) dan tidak statis. Identitas budaya adalah rincian karakteristik atau ciri-ciri sebuah kebudayaan yang dimiliki oleh sekelompok orang yang kita ketahui batas-batasnya tatkala dibandingkan dengan karakteristik atau ciri-ciri kebudayaan orang lain (Liliweri, 2013:86).

Dengan peryataan tersebut berarti jika ingin mengetahui dan menetapkan identitas budaya, maka tidak sekedar menentukan karakteristik, ciri-ciri fisik atau biologis semata tetapi mengkaji identitas kebudayaan sekelompok manusia melalui tatanan berpikir (cara berpikir, orientasi berpikir), perasaan (cara merasa dan orientasi perasaan), dan cara bertindak (motivasi tindakan atau orientasi tindakan). Dalam praktik komunikasi, identitas tidak hanya memberikan makna tentang pribadi seseorang, tetapi lebih dari itu, menjadi ciri khas sebuah kebudayaan yang melatarbelakanginya (Liliweri, 2007:76).

Ketika manusia itu hidup dalam masyarakat yang multibudaya, maka di sanalah identitas budaya itu diperlukan. Identitas budaya merupakan ciri yang ditunjukkan seseorang karena orang itu merupakan anggota dari sebuah kelompok etnik tertentu. Itu meliputipembelajaran tentang dan penerimaan tradisi, sifat bawaan, bahasa, agama, keturunan dari suatu kebudayaan (Liliweri, 2004:87).

Liliweri (2013:86) mengemukakan juga untuk menentukan identitas budaya sangat bergantung pada bahasa (bahasa sebagai unsur kebudayaan nonmaterial), yaitu bagaimana representasi bahasa menjelaskan sebuah kenyataan atas semua identitas yang dirinci dan dibandingkan. Dalam perspektif komunikasi, identitas yang menekankan sifat dari interaksi self group (interaksi yang diakukan seorang pribadi dan interaksi kelompok merupakan suatu yang bersifat komunikatif. Identitas dibangun melalui interaksi sosial dan komunikasi, identitas dihasilkan oleh negoisasi melalui media, yakni media bahasa.

Identitas seseorang dapat ditentukan oleh tampilan pribadi (avowel). Inilah identitas saya, faktor penentu berikut tergantung dari bagaimana orang lain memberikan atribusi atas askripsi. Diperkuat oleh Anoegrajekti (2008:234) Identitas budaya terdiri dari tiga aspek, yaitu keunikan, kepribadian, dan peran yang dijalankan. Keunikan berisi ciri khas yang terdapat dalam kesatuan budayanya. Kepribadian berisi nilai-nilai budaya yang menjadi aspirasi, tujuan masa depan, dan orientasi hudupnya. Peran berisi kemampuan untuk menempatkan diri dan beriorientasi dalam lingkungannya. Dalam praktik komunikasi, identitas tidak hanya memberikan makna tentang pribadi seseorang, tetapi lebih dari itu, menjadi ciri khas sebuah kebudayaan yang melatarbelakanginya. Ketika manusia itu hidup dalam masyarakat yang multibudaya, maka di sanalah identitas budaya itu diperlukan. Identitas tiap daerah satu dengan yang lainnya akan berbeda, karena adanya kebiasaan setiap daerah yang berbeda pula. Identitas budaya ini dapat dikatakan sebagai suatu karakter yang melekat dalam suatu kebudayaan, sehingga bisa dibedakan antara satu kebudayaan dengan kebudayaan yang lain.

Jadi, identitas budaya terbentuk melalui struktur kebudayaan suatu masyarakat. Struktur budaya adalah pola-pola persepsi, berpikir, dan perasaan. Identitas budaya dapat diartikan sebagai cerminan kesamaan sejarah yang membentuk sekelompok orang menjadi satu walaupun dari luar mereka tampak berbeda. Hal ini berarti dari kesamaan sejarah yang menyatukan mereka. Oleh karenanya, identitas budaya suatu daerah merupakan suatu karakter atau jati diri dari suatu daerah akan budayanya yang menjadi hasil karya suatu daerah tersebut. Dengan demikian, dapat dikatakan bahwa identitas budaya difungsikan untuk memperkenalkan suatu daerah kepada daerah lainnya. 
Identitas budaya merupakan ciri yang ditunjukkan seseorang karena orang itu merupakan anggota dari sebuah kelompok etnik tertentu. Identitas budaya meliputi pembelajaran tentang dan penerimaan tradisi, sifat bawaan, bahasa, agama, keturunan dari suatu kebudayaan. Simatupang (2013:220) mengutarakan bahwa tradisi merupakan kebiasaan dimasa silamyang merujuk paa tindakan-tindakan yang serta-merta dilakukan bila terpicu ileh suatu situasi-kondisi tertentu. Pada umumnya hanya kebiasaankebiasaan tertentu yang dianggap bernilai positif bagi masyarakat pelakunya sajalah yang dinamakan tradisi. Sebaliknya adat merupakan kebiasaan, dalam praktiknya adat sering dimasukkan ke dalam salah satu rujukan hukum (Hadi, 2010:173). Dikuatkan oleh Simatupang (2013:221) bahwa adat sering digunakan secara lebih terbatas untuk merujuk pada kebiasaankebiasaan yang kepastian pelaksanaanya ditopang oleh sebuah sistem sanksi yang ditetapkan oleh masyarakat setempat.

Sebagai contoh untuk mengidentifikasi sekelompok orang keturunan di Timor Timur sebagai sekelompok orang yang mempunyai kebudayaan tersendiri. Identik dengan parlente, suka minum, bersuka ria, tak mau diatur, dan suka pesta (Liliweri 2013:87). Dalam pengertian ini adat hamper sama dengan sistem hokum pada kehidupan modern, ditopang oleh sistem pengaturan otoritas, merangkum soal hak dan kewajiban da nada sanksi bagi yang melanggarnya. Dengan demikian yang membedakan tradisi dengan adat adalah tradisi menyandarkan diri sepernuhnya pada aspirasi warga masyarakat, pada adat hal tersebut ditopang oleh sanksi. Dari seluruh uraian di atas dapat disimpulkan bahwa identitas budaya merupakan suatu karakteristik tertentu dari sebuah kelompok ataupun golongan. Karakteristikitu merupakan penunjuk untuk mengenal kelompok sehingga akan mengetahui dan memudahkan dalam berkomunikasi dengan suatu kelompok.

Adapun faktor-faktor pembentuk identitas budaya musik gambus sebagai pembentuk masyarakat di Kota Palembang adalah kepercayaan, bahasa dan pola perilaku.Dari peryataan diatas dapat dikatakan musik gambus merupakan bagian dari kebudayaan Kota Palembang. ini akan dijelaskan lebih rinci dengan masing-masing pemahaman tentang kepercayaan, bahasa dan pola perilaku dalam (Liliweri 2002: 87).

\section{Kepercayaan}

Liliweri (2007: 111) mengemukakan bahwa kepercayaan adalah usaha untuk menerima sebuah kebenaran tentang sesuatu yang dipelajari dalam kebudayaan. Kepercayaan merupakan pusat dari tindakan manusia yang menunjukkan bagaimana berprilaku di dunia. Kepercayaan manusia merupakan dasar dari penerimaan nilai-nilai. Kepercayaan menjadi faktor utama dalam identitas budaya, tanpa adanya kepercayaan yang dianut maka tidak akan terbentuk suatu identitas budaya yang melekat pada suatu kebudayaan. Liliweri (2013: 108) mengemukakan kepercayaan atau keyakinan yang merupakan konsep manusia tentang segala sesuatu disekelilingnya. Jadi, kepercayaan atau keyakinan itu menyangkut gagasan manusia tentnag individu, orang lain serta semua aspek yang berkaitan dengan biologi, fisik, sosial dan dunia supernatural. Kepercayaan atau keyakinan memang dimiliki oleh semua suku bangsa yang pada awalnya bersumber dari kepercayaan dalam kebudayaannya. Kepercayaan memberikan langkah atau cara untuk menginterpretasi dan menjelaskan dunia. Keragaman kepercayaan dan keyakinan dapat membantu orang untuk merasa terlibat banyak atau sedikit dalam berbagai peristiwa (Liliweri 2007: 56).

Jika menurut akan penjelasan yang diberikan oleh Liliweri, maka dapat dikatakan, karena keakraban budaya yang ditemukan merupakan perwujudan antar budaya yang dipercayai oleh masyarakat Palembang, dan kemudian dijadikan sebagai pedoman hidup dalam kehidupan bermasyarakat. Eratnya hubungan keakraban maupun perwujudan antara etnis arab dan masyarakat Palembang serta faktor kepercayaan pembentuk identitas budaya Palembang, dan ini terjalin karena bersatunya agama dan kebudayaan yang terdapat di Kota Palembang. Seperti yang dijelaskan para tokoh- 
tokoh, seniman, maupun narasumber beberapa kelompok-kelompok musik gambus di Kota Palembang, hukum Islam dan adat merupakan suatu kesatuan yang tidak dapat dipisahkan. Hal itu berlaku dalam segala cabang kehidupan baik itu politik, ekonomi, keuangan, sosial budaya, dan tata susila. Segala macam ajaran dan sistem kemasyarakatan harus menyesuaikan dengan ajaran Islam.

Kepercayaan adalah gejala yang bersifat intelektual terhadap kenyataan dari sesuatu atau kebenaran suatu pendapat. Biasanya kepercayaan ini muncul dari amanah para leluhur terdahulu yang menyakini tentang suatu kegiatan yang biasa dilakukan oleh suatu budaya yang tentunya berbeda antara budaya satu dengan budaya lainnya. Contohnya, mempercayai tradisi pecah telur pada saat resepsi pernikahan yang dipercaya sebagai salah satu tradisi penting masyarakat Jawa dalam resepsi pernikahan. Geertz (1992: 5) mengatakan bahwa agama adalah: (1) Sebuah sistem simbol-simbol yang berlaku untuk (2) menetapkan suasana hati dan motivasi-motivasi yang kuat, yang meresapi dan yang tahan lama dalam diri manusia dengan (3) merumuskan konsep-konsep mengenai suatu tatanan umum eksistensi dan (4) membungkus konsep-konsep ini dengan semacam pancaran faktualitas, sehingga (5) suasana hati dan motivasi tampak realistis.

\section{Bahasa}

Dalam komunikasi antar manusia seharihari kita diperkenalkan oleh istilah-istilah seperti bahasa lisan, bahasa tulisan, bahasa isyarat, bahasa jarak dan lain-lain. Semuanya itu merupakan gambaran tentang aspek pragmatis dari penggunaan bahasa. Bahasa merupakan alat utama yang digunakan budaya untuk mewariskan kepercayaan, nilai dan norma. Kebudayaan ditemukan hanya dalam masyarakat manusia, sebab hanya manusia yang dapat mengembangkan sistem simbol dan menggunakannya secara lebih baik. Bahasa terdiri dari susunan kata-kata, kata-kata disusun oleh simbol sehingga bahasa merupakan susunan berlapis-lapis dari simbol yang ditata menurut ilmu bahasa (Liliweri 2007: 57).
Bahasa merupakan alat untuk berinteraksi dengan orang lain dan juga sebagai alat untuk berpikir. Dalam konteks ini, bahasa berfungsi sebagai suatu mekanisme untuk berkomunikasi dan sekaligus sebagai pedoman untuk melihat realitas sosial. Bahasa mempengaruhi persepsi, menyalurkan dan turut membentuk pikiran. Kita memahami bahasa lisan hanya karena penggunaan bahasa itu melalui alat ucap yang dalam istilah komunikasi disebut oral communication. Selain penyampaian pesan dilakukan dengan oral/lisan maka kadangkadang kita mengalihkan pesan melalui tulisan itulah yang disebut verbal communication (Liliweri 2002: 131).

Pada bidang linguistik bahasa diberi definisi serta alam studi kebudayaan, bahasa ditempatkan sebagai sebuah unsur penting. Bahkan bahasa dapat dikategorikan sebagai unsur kebudayaan yang berbentuk non material selain nilai, norma dan kepercayaan. Berbahasa adalah pernyataan kepuasan dan dipelajari secara tidak disadari. Bahasa dan kebudayaan selalu terealisasi secara tumpang tindih (Liliweri 2002: 134).

Hal ini tampak dalam salah satu baris syair lagu "Salawat Badar" yang mana Salawat Badar merupakan salah satu salawat yang didalamnya tersusun dari untaian kata-kata indah yang membawa kita untuk senantiasa bermahabah mencintai Rasulillah. Di dalamnya, selain berisi ungkapan salawat ke atas Nabi, juga terdapat doa-doa yang dimohonkan kepada Allah Yang Maha Menjawab. Hal ini yang membentuk konstruk berpikir masyarakat Palembang tentang tata bahasa yang baik dalam ber'doa, berbicara, maupun bergaul di masyarakat, dan juga terwujud dari cara masyarakat Palembang memperlihatkan kecintaannya terhadap kebudayaannya sendiri. Terbukti dengan seringnya menggunakan pertunjukan musik gambus dalam setiap kegiatan, baik itu pernikahan, khitanan, serta acara-acara di pemerintahan. Sebagaimana yang dijelaskan oleh Liliweri (2007: 57) yang menyatakan bahwa bahasa mempengaruhi persepsi, menyalurkan dan turut membentuk pikiran. 


\section{Pola Perilaku}

Pola perilaku juga menjadi faktor pembentuk identitas budaya, bagaimana pola perilaku kita dimasyarakat mencerminkan identitas budaya yang kita anut. Dalam hal ini biasa terjadinya diskriminasi terhadap orang-orang tertentu yang berperilaku kurang baik menurut orang sekitarnya yang pada umumnya didalam budaya orang tersebut adalah sesuatu yang wajar dilakukan. Tingkah laku yang tidak dipelajari dari organisme menunjuk kepada aktivitasaktivitas yang seringkali disebut refleks dan insting yang pola utamanya didapatkan melalui keturunan.

Perilaku manusia yang tidak dipelajari membentuk bagian dari sifat-sifat asli. Perilaku manusia yang dipelajari termasuk kebiasaankebiasaan, sikap-sikap emosi dan semua bentuk aktivitas dan tanggapan-tanggapan yang didapatkan melalui pengalaman (Mintargo 1997: 43). Ringkasnya, kegiatan-kegiatan yang tidak dipelajari yang dibawa sejak lahir pada individu, tidak didapatkan melalui pengalaman atau aktivitas. Kemudian akan berubah melalui latihan atau lingkungan. Aktivitas-aktivitas yang dipelajari yaitu yang dihasilkan dari pengalaman-pengalaman sebelumnya.

Mintargo (1997: 43) mengatakan bahwa tingkah laku manusia lebih banyak merupakan hasil dari kegiatan-kegiatan yang dipelajari dari pada yang tidak dipelajari. Sejak perilaku manusia lebih banyak merupakan hasil belajar, perubahan atau modifikasi melalui aktivitas. Manusia hidup dalam suasana yang lebih bebas dan fleksibel dan lebih banyak memiliki kemungkinan untuk berkembang. Kegiatan manusia tidak seperti semut, lebah, burung dan bentuk kehidupan binatang lainnya, tidak terikat ketat dengan pembatasan pada tingkah laku yang dibawa sejak lahir seperti insting. Manusia dapat memilih tindakan-tindakannya untuk menyesuaikan dengan kebutuhan fisik ataupun lingkungan sosialnya.

Dengan begitu tata cara berpakaian pemain pemusik-pemusik maupun penyanyi mencerminkan identitas budaya Palembang.Apa yang dipercayai oleh masyarakat Palembang diamalkan dan dijadikan pedoman hidup.
Menyesuaikan dengan adat dan agama Islam yang menghimbau agar laki-laki tidak banyak menggunakan riasan dan perhiasan. Hal ini dilakukan agar para pemain musik gambus di Kota Palembang tidak terlihat seperti wanita, justru memperlihatkan kesopanan, kesederhanaan, dan kegagahan dari seorang laki-laki. Dengan begitu apa yang dipercayai etnis Arab, kemudian digunakan sebagai pedoman dalam berprilaku di masyarakat Kota Palembang, seperti menggunakan riasan wajah yang wajar menurut masyarakat menjadi identitas budaya Kota Palembang.

\section{KESIMPULAN}

Musik gambus melayu merupakan salah satu genre seni musik yang lahir dari perpaduan budaya Timur Tengah dan Melayu di Kota Palembang. Masyarakat etnis Arab juga memiliki prilaku, kebiasaan, maupun keakraban terhadap masyarakat-masyarakat Kota Palembang. Beberapa etnis Arab yang ada di Kota Palembang dapat dikatakan sebagai minoritas, akan tetapi, ada beberapa etnis (suku) Arab yang memunculkan identitas estetik masyarakat di Kota Palembang dengan mempertunjukan kesenian-kesenian mereka, dan etnis Arab yang mempertahankan kebudayaan mereka melalui kesenian musik gambus. Aliran musik ini bukan genre baru, tetapi telah hadir sejak ratusan tahun lalu seiring bertumbuh kembangnya etnis Arab di bumi Sriwijaya. Melalui hasil pendekatan historis masuknya kebudayaan Arab di Kota Palembang, yang mencerminkan identitas budaya Kota Palembang, terdapat temuan yakni beberapa keakraban dari perwujudan yang menjadi penyajian musik gambus di lingkungan Kota Palembang. Dalam beberapa faktor, yang membentuk identitas budaya Palembang ialah pembentukan identitas budaya musik gambus sebagai pembentuk masyarakatdi Kota Palembang yang menjadi kepercayaan, bahasa dan pola perilaku.

\section{DAFTAR PUSTAKA}

Anoegrajekti, Novi. (et. al.0 2008. Estetika Sastra, Seni dan Budaya. Jakarta: UNJ Press. 
Arifin, Zainal. "Fungsi Gambus dalam Musik Melayu Deli di Sumatera Utara", Jurnal Greneg, hlm. 67-75.

Cahyono, Agus dan Muh. Jazuli. 1996. Gambang Semarang Sebuah Pencarian Identitas (Tinjauan dari Segi Historis). Jurnal Media No 2 Th XIX Hal 86-96. FPBS IKIP Semarang.

Geertz, Clifford, 1992. Kebudayaan dan Agama. Yogyakarta: Refleksi Budaya.

Hadi, Y Sumandiyo. 2011. Koreografi (BentukTeknik-isi). Yogyakarta: Cipta Media.

Hadi, Y Sumandiyo, 2012. Seni pertunjukan dan Masyarakat Penonton. Yogyakarta: Perpustakaan Nasional, KDT.

Haryanto, Nia. 2013. Pancasila, Sumber Nilai-nilai Dasar dan Penguat Identitas Bangsa di Mata Dunia, dalam "http:// www.niaharyanto.com/2013/03/pancasilasumber-nilai-nilai-dasar.html", diakses pada 17 Desember 2016.

Jamalus, 1988. Musik dan Praktek Perkembangan Buku Sekolah Pendidikan Guru. Jakarta: CV. Titik Terang.

Kinasih, Ayu Windy. 2007. Identitas Etnis Tionghoa di Kota Solo. Jurnal, Yogyakarta: Universitas Gadjah Mada.

Koentjaraningrat. 1984. Kebudayaan Mentaluitet dan Pembangunan. Jakarta: PT. Gramedia Pustaka Utama.

Koentjaraningrat. 2000. Pengantar Ilmu Antropologi. Jakarta: Rineka Cipta.

Kumbara, Hendra. "Bentuk Ekspresi Musikal Kesenian Musik Gambus El Mata di Pekalongan", Skripsi, Unnes Semarang 2013.
Liliweri, Alo. 2001, Gatra-gatra Komunikasi Antarbudaya. Yogyakarta: Pustaka Pelajar.

Liliweri, Alo. 2002. Makna Budaya dalam Komunikasi Antarbudaya. Yogyakarta: Lkis.

Liliweri, Alo. 2007. Makna Budaya dalam Komunikasi Antar Budaya. Yogyakarta: Lkis.

Liliweri, Alo. 2013. Dasar-Dasar Komunikasi Antar Budaya. Yogyakarta: Pustaka Pelajar.

Liliweri, Alo. 2014. Pengantar Studi Kebudayaan. Bandung: Nusa Media.

Mintargo, Bambang, 1997. Manusia dan Nilai Budaya. Jakarta: universitas Trisakti.

Mulyana, Deddy, dan Jalaludin Rakhmat, 2006, Panduan Berkomunikasi dengan Orangorang Berbeda Budaya, Bandung: Remaja Rosdakarya.

Simatupang, Lono, 2013. Pergelaran (Sebuah Mozaik Penelitian Seni-Budaya). Yogyakarta: Jalasutra

Soekanto, Soerjono. 1986. Sosiologi Suatu Pengantar. Jakarta:Rajawali Pers.

Soekanto, Soerjono. 2012. Sosiologi Suatu Pengantar. Jakarta: Rajawali Press.

Sugiharto, Bambang, 2013. Untuk Apa Seni?, Bandung: Pustaka Matahari.

Sunarto. "Studi Salawat Diba'an di Dusun Watukarung 1, Kelurahan Margoagung dalam Konteks Pengaruh Idom Persia”. Skripsi, ISI Yogyakarta 1994.

Verulitasari, Esti. 2016. "Pertunjukan Rapai Geleng, Sebuah Pencarian Identitas Budaya Aceh". Tesis, Unnes Semarang. 